\title{
Determination of Persistence of Fungicide in Seeds and Seedlings of Sunflower
}

\author{
A. Srinivas", B. Pushpavathi, B.K.M. Lakshmi and V. Shashibushan \\ Department of Plant Pathology, College of Agriculture, Professor Jayashankar Telangana State \\ Agricultural University, Hyderabad-500030, Telangana, India \\ *Corresponding author
}

A B S T R A C T

\begin{tabular}{|c|c|}
\hline Keywords & \\
\hline $\begin{array}{l}\text { LC-MS/MS, } \\
\text { Fungicide residues, } \\
\text { Vitavax power, } \\
\text { Dissipation of } \\
\text { carboxin. }\end{array}$ & \multirow{3}{*}{$\begin{array}{l}\left.\text { Sunflower seeds were treated carboxin + thiram (Vitavax power @ } 3 \mathrm{~g} \mathrm{~kg}^{-1}\right) \\
\text { and the systemic component carboxin was analysed in seeds and seedlings } \\
\text { upto one month period at weekly intervals using LC-MS/MS. Maximum } \\
\text { residues of carboxin were recorded in sunflower seeds }(282.92 \mathrm{mg} \mathrm{kg} \text { ) } \\
\text { stored for a week, in seedlings }(0.63 \mathrm{mg} \mathrm{kg} \text { ) at immediately after } \\
\text { emergence (zero days). Fungicide residues were found to be very less in } \\
\text { seedlings when compared to seeds and this can be attributed to degradation } \\
\text { of fungicide at the time of seedling emergence and its further growth. }\end{array}$} \\
\hline Article Info & \\
\hline $\begin{array}{l}\text { Accepted: } \\
\text { xx August } 2017 \\
\text { Available Online: } \\
\text { xx October } 2017\end{array}$ & \\
\hline
\end{tabular}

\section{Introduction}

Sunflower (Helianthus annuus L.) is one of the most popular oilseed crops grown in India. Sunflower seeds contain $40-50 \%$ oil, $23 \%$ of protein and constitute excellent source of unsaturated fats, fiber and important nutrients, linoleic acid, selenium, copper, zinc, vitamin $\mathrm{E}$ and $\mathrm{B}$ complex as well (Afzal et al., 2010). The total area of sunflower in India is $0.69 \mathrm{Mha}$ with a production of $0.50 \mathrm{Mt}$. It occupies $6^{\text {th }}$ place among the oilseed crops grown in India in terms of production (Indiastat, 2013-14). Karnataka and Andhra Pradesh are the major sunflower growing states in India.

Seed health plays an important role in successful cultivation and yield exploration of a crop. Fungi are the main component of microflora associated with seeds and are the main cause of deterioration and loss observed during storage (Tanaka et al., 2001). Seeds are known to harbour several fungi which may cause seed rot, seedling mortality, reduced seedling vigour and seed viability which leads to poor plant stand in the field.

Seed treatment is one of the best methods to manage seedborne diseases. It has become a common practice to use fungicides as seed dressers for reducing the seedborne infections under field conditions. Fungicides form a zone of protection over the seed surface that reduces seed decay and seedling blight, resulting in healthy and vigorous seedlings. 
Treating the seeds with fungicides may eradicate pathogens in or on seeds and can also protect seeds and seedlings from soilborne pathogens (Maude, 1996). After germination of the treated seed, fungicide gets absorbed and moves systemically throughout the seedling or plant. Seed treatment protects the germinated seedling upto one month from targeted disease for which it is applied. Measuring the fungicide residues in seedlings upto certain age gives the idea about dissipation rate of the fungicide in seedlings and the residues level can be correlated with the disease level in the field if any. In the present study, the fungicide carboxin was tested for its residues in treated seeds and seedlings grown from treated seeds upto one month period at weekly intervals.

\section{Materials and Methods}

The seeds of sunflower (DRSH-1) were treated with carboxin + thiram (Vitavax power@3 $\mathrm{g} \mathrm{kg}^{-1}$ ), stored in butter paper bags and the systemic component of the treated fungicide carboxin was analyzed for its residues in seeds and seedlings upto one month period at weekly intervals.

Treated seeds were sown in earthen pots and the seedlings raised were analyzed for the presence of carboxin residues at weekly intervals upto one month age.

\section{Preparation of working standards}

Certified Reference Material (CRM) of carboxin from Sigma - Aldrich, United States was utilized for preparing primary, intermediary and working standards of carboxin.

Carboxin working standards in the range of $10 \mathrm{ppb}$ to $100 \mathrm{ppb}$ were prepared in $10 \mathrm{ml}$ calibrated graduated volumetric flasks using distilled methanol as the solvent. All standards were stored in deep freezer maintained at $-40^{\circ} \mathrm{C}$.

\section{Limit of detection and linearity test}

The working standards of carboxin were injected in Liquid Chromatography - Mass Spectrometer (LC-MS/MS) for estimating the lowest quantity of carboxin that can be detected. The standard operating parameters are given in Table 1.

Under the mentioned LC-MS/MS operational parameters, the retention time of carboxin was minimum. Each working standard of carboxin (10 ppb, $20 \mathrm{ppb}, 40 \mathrm{ppb}, 60 \mathrm{ppb}, 80 \mathrm{ppb}$ and $100 \mathrm{ppb}$ ) was injected six times and linearity graph was drawn (Fig. 1). Based on the response of the mass spectrometer, it was found that the LOD (Limit of Detection) for carboxin was $0.01 \mathrm{ppm}$ with the linearity in the range of $0.01 \mathrm{ppm}$ to $0.5 \mathrm{ppm}$.

\section{Validation of method}

Prior to the actual sample analysis, the residue analysis method was validated by following the principle as per SANCO (12571/2013) document. For this purpose, the samples were prepared using untreated seeds and seedlings. The sample was homogenized using Robo Coupe Blixerand homogenized sample of $15 \mathrm{~g}$ each was taken in to $50 \mathrm{ml}$ centrifuge tubes. The required quantity of carboxin intermediary standard prepared from CRM was added to each $15 \mathrm{~g}$ sample to get fortification levels of $0.05 \mathrm{ppm}, 0.25 \mathrm{ppm}$ and $0.5 \mathrm{ppm}$ in three replications. These fortification levels were selected to know the suitability of the method to detect and quantify carboxin in sunflower and groundnut below Maximum Residue Limits (MRLs) of Codex Alimentarius Commission. As the MRLs of carboxin in sunflower are not available, the MRL of rape seed $(0.03 \mathrm{ppm})$ was considered for the present study. The 
AOAC official method (2007.01) was slightly modified to suit to the facilities available at the laboratory and the same was validated for estimation of LOQ (Limit of Quantification) of carboxin in sunflower matrix. The method followed is explained below. The final extract of the sample i.e. $2 \mathrm{ml}$ which is equal to $1 \mathrm{~g}$ of the sample was injected to LC-MS/MS. The fortified samples in replications were analyzed on LC-MS/MS following the operational conditions and the residues of fungicide recovered from fortified samples were calculated using the following formula.

Sample peak area $\mathrm{x}$ concentration of standard $(\mathrm{ppm}) \times$ standard injected $(\mu \mathrm{l}) \times$ final volume Residues $\left(\mathrm{mg} \mathrm{kg}^{-1}\right)=$

of the sample $(\mathrm{ml})$

Standard peak area $\mathrm{x}$ weight of sample analysed $(\mathrm{g})$ x sample injected $(\mu \mathrm{l})$

Sample weight $(\mathrm{g}) \mathrm{x}$ aliquot taken $(\mathrm{ml})$ Weight of the sample analysed =

Volume of acetonitrile $(\mathrm{ml})$

The per cent recovery was calculated using the following formula

Residue quantified in fortified sample Per cent recovery $=$

Fortified level

\section{QuEChERS method for seed samples}

Seed sample (250g) was ground, weighed about $10.0 \pm 0.1 \mathrm{~g}$ samples each into $50 \mathrm{ml}$ centrifuge tube and $20 \mathrm{ml}$ distilled water was added. Then, $20.0 \pm 0.1 \mathrm{ml}$ acetonitrile was added to this centrifuge tube, capped and shaken well.

The sample was homogenized at 14,000$15,000 \mathrm{rpm}$ for $2-3 \mathrm{~min}$. To that, $3 \pm 0.1 \mathrm{~g}$ $\mathrm{NaCl}$ was added, mixed by shaking vigoursly and kept in refrigerator for $10 \mathrm{~min}$. Then, centrifuged for $3 \mathrm{~min}$ at $2500-3000 \mathrm{rpm}$ to separate organic layer. Approximately $12 \mathrm{ml}$ of upper organic layer was taken in a test tube and $5 \pm 0.1 \mathrm{~g} \mathrm{Na}_{2} \mathrm{SO}_{4}$ (Anhydrous) was added to remove moisture content. $0.20 \pm 0.01 \mathrm{~g}$ PSA sorbent and $0.60 \pm 0.01 \mathrm{~g}$ anhydrous $\mathrm{MgSO}_{4}$ was weighed into $15 \mathrm{ml}$ centrifuge tubes for $8 \mathrm{ml}$ organic layer (extract). $8 \mathrm{ml}$ of extract was transferred to the centrifuge tube, capped and vortexed for $30 \mathrm{sec}$. The tubes were centrifuged for $5 \mathrm{~min}$ at 2500-3000 rpm. $1 \mathrm{ml}$ extract was transferred to $15 \mathrm{ml}$ centrifuge tube, acetonitrile of $1 \mathrm{ml}$ was added and centrifuged at 2500-3000 rpm for 5 min. Then, filtered with PTFE $(0.22 \mu \mathrm{m})$ syringe filter. The filtrate was transferred in vials for residue analysis on LC-MS/MS $\left(0.25 \mathrm{~g}\right.$ of sample $\left.\mathrm{ml}^{-1}\right)$

\section{QuEChERS method for seedling samples}

Seedlings $(250 \mathrm{~g})$ were ground and weighed about $15.0 \pm 0.1 \mathrm{~g}$ samples each into $50 \mathrm{ml}$ centrifuge tube. Then, $30.0 \pm 0.1 \mathrm{ml}$ acetonitrile was added to this centrifuge tube, capped and shaken well. The sample was homogenized at 14,000-15,000 rpm for 30 min. Next, $3 \pm 0.1 \mathrm{~g}$ of $\mathrm{NaCl}$ was added and shaken gently.

Centrifuged for $3 \mathrm{~min}$ at $2500-3000 \mathrm{rpm}$ to separate the organic layer. $16 \mathrm{ml}$ of organic layer was taken into $50 \mathrm{ml}$ tube having $9 \mathrm{~g}$ sodium sulphate and mixed thoroughly. From that, $8 \mathrm{ml}$ of extract was taken into $15 \mathrm{ml}$ centrifuge tube with $1.2 \mathrm{~g}$ of $\mathrm{MgSo}_{4}$ and $0.4 \mathrm{~g}$ PSA and centrifuged for 2 min at $2500 \mathrm{rpm} .2$ $\mathrm{ml}$ of supernatant layer was taken into $15 \mathrm{ml}$ tube and filtered through PTFE filter $(0.22 \mu \mathrm{m}) .1 \mathrm{ml}$ filtrate was taken into LC vial for analysis on LC-MS/MS directly.

\section{Limit of quantification (LOQ)}

Samples fortified with carboxin at $0.05,0.25$ and $0.5 \mathrm{ppm}$ were analyzed as per the QuEChERS (Quick, Easy, Cheap, Effective, Rugged and Safe) method. The mean recovery of the residues recorded through this method was $80.25 \%, 94.52 \%$ and $115.46 \%$ in 
sunflower seeds, $77.99 \%, \quad 93.42 \%$ and $113.34 \%$ in sunflower seedlings at $0.05,0.25$ and $0.5 \mathrm{ppm}$ fortification levels respectively (Table 2).

The results showed that the QuEChERS method was suitable for the analysis of carboxin residues upto $0.05 \mathrm{ppm}$, which was considered as the LOQ of carboxin. Hence, the QuEChERS method described was used to study the residue dynamics or dissipation pattern of carboxin residues in sunflower seeds and seedlings.

\section{Dissipation pattern of carboxin}

After the validation of method, the seeds and seedlings were analyzed for carboxin residues persisting in them by LC-MS/MS. The residues of carboxin were calculated by using the formula mentioned earlier. The per cent dissipation of carboxin was calculated by using the following formula.

Initial deposit - residues at given time Per cent dissipation = ---------------------- x 100 Initial deposit

\section{Results and Discussion}

As carboxin is systemic in nature, its residues were analysed in seeds and seedlings by using LC-MS/MS. The residues in seeds were analysed immediately after treatment upto one month after treatment at weekly intervals, whereas the seedlings were analysed immediately after germination upto one month age of seedlings at weekly intervals.

\section{Dissipation in seeds}

Dissipation pattern of carboxin was studied in seeds and the data is presented in Table 3. Significantly highest residues of carboxin were recorded in seeds stored for a week (282.92 $\mathrm{mg} \mathrm{kg}^{-1}$ ) which was at par with seeds analysed at zero days after seed treatment (271.82 $\mathrm{mg} \mathrm{kg}^{-1}$ ) followed by two weeks $\left(213.21 \mathrm{mg} \mathrm{kg}^{-1}\right)$ and three weeks (190.83 mg $\mathrm{kg}^{-1}$ ) after storage and the least $(136.83 \mathrm{mg}$ $\mathrm{kg}^{-1}$ ) of that was found in seeds stored for a month (Fig. 2). The residues dissipated by $4.08,21.56,29.80$ and $49.66 \%$ in one week, two weeks, three weeks and one month stored samples respectively.

Table.1 Standard operating parameters of LC-MS/MS

\begin{tabular}{|l|l|}
\hline LC-MS/MS & SHIMADZU LC-MS/MS 8040 \\
\hline Detector & Mass spectrophotometer \\
\hline Column & KINETEX, 100x3,2 $\mu \mathrm{m}$ \\
\hline Column Oven Temperature $\left({ }^{0} \mathrm{c}\right)$ & $40^{0} \mathrm{c}$ \\
\hline Retention time $(\mathrm{RT})$ & $2.163 \mathrm{~min}$ \\
\hline Nebulizing gas & Nitrogen \\
\hline Nebulizing gas flow & 2.0 lit $\mathrm{min}^{-1}$ \\
\hline Pump Mode/Flow & Gradient $0.4 \mathrm{ml}^{-1} \mathrm{~min}^{-1}$ \\
\hline LC - Programme & $\mathrm{A}:$ Ammonium formate in water - 40 \\
\cline { 2 - 2 } & $\mathrm{B}:$ Ammonium formate in methanol - 60 \\
\hline Total programme & 5.00 min $^{-1}$ \\
\hline Precursor ion & 236 \\
\hline Quantifier ion & 143 \\
\hline Qualifier ion & 43 \\
\hline
\end{tabular}


Table.2 Recovery of carboxin from fortified samples of sunflower and groundnut

\begin{tabular}{|c|c|c|c|c|}
\hline \multirow{2}{*}{$\begin{array}{c}\text { Fortification } \\
\text { level } \\
(\mathbf{p p m})\end{array}$} & \multicolumn{3}{|c|}{ Seed } & \multicolumn{2}{|c|}{ Seedling } \\
\cline { 2 - 5 } & $\begin{array}{c}\text { Recovered } \\
\text { residues }\end{array}$ & Recovery (\%) & $\begin{array}{c}\text { Recovered } \\
\text { residues }\end{array}$ & Recovery (\%) \\
\hline $\mathbf{0 . 0 5}$ & 0.040 & 80.25 & 0.039 & 77.99 \\
\hline $\mathbf{0 . 2 5}$ & 0.236 & 94.52 & 0.234 & 93.42 \\
\hline $\mathbf{0 . 5}$ & 0.577 & 115.46 & 0.567 & 113.34 \\
\hline
\end{tabular}

Table.3 Dissipation of carboxin in seeds and seedlings of sunflower

\begin{tabular}{|c|c|c|c|c|}
\hline \multirow{2}{*}{$\begin{array}{c}\text { Storage } \\
\text { period / Age } \\
\text { of seedlings }\end{array}$} & \multicolumn{2}{|c|}{ Seeds } & \multicolumn{2}{c|}{ Seedlings } \\
\cline { 2 - 5 } & $\begin{array}{c}\text { Residues } \\
\left(\mathbf{m g ~ k g}^{-\mathbf{1}}\right)\end{array}$ & $\begin{array}{c}\text { Dissipation } \\
(\%)\end{array}$ & $\begin{array}{c}\text { Residues } \\
\left(\mathbf{m g ~ k g}^{-1}\right)\end{array}$ & $\begin{array}{c}\text { Dissipation } \\
(\%)\end{array}$ \\
\hline 0 days & $271.82 *$ & 0.00 & 0.632 & 0.00 \\
\hline 1 week & 282.92 & -4.08 & 0.033 & 94.78 \\
\hline 2 weeks & 213.21 & 21.56 & 0.032 & 94.94 \\
\hline 3 weeks & 190.83 & 29.80 & 0.029 & 95.41 \\
\hline 1 month & 136.83 & 49.66 & 0.000 & 100.00 \\
\hline SE(m) \pm & 4.84 & & 0.007 & \\
\hline CD at 5\% & 14.73 & & 0.022 & \\
\hline
\end{tabular}

* Mean of three replications

Fig.1 Linearity of carboxin

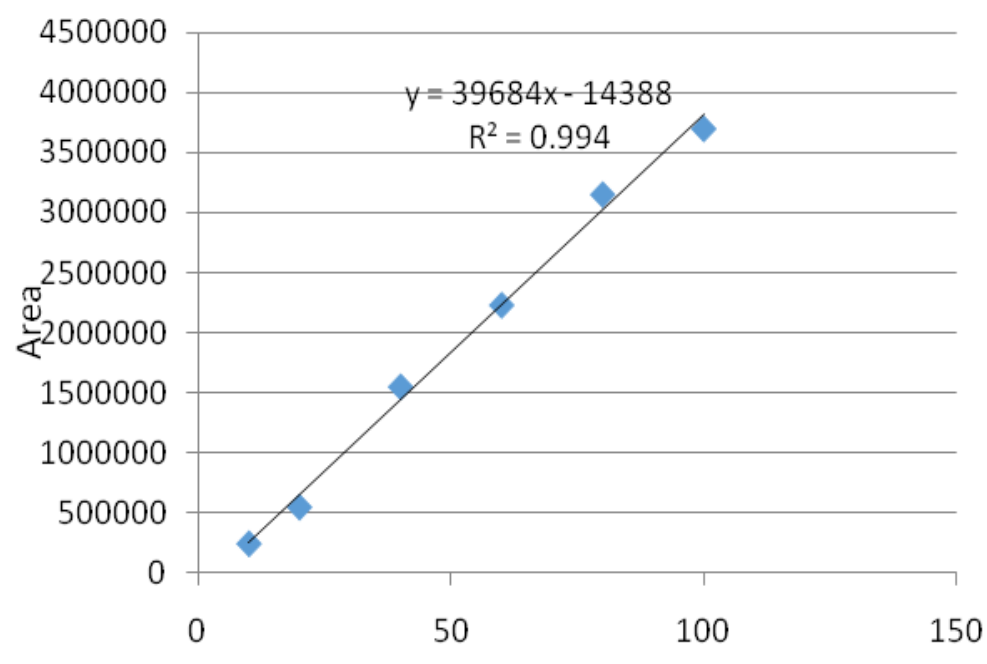

Concentration 
Fig.2 Dissipation of carboxin in seeds of sunflower

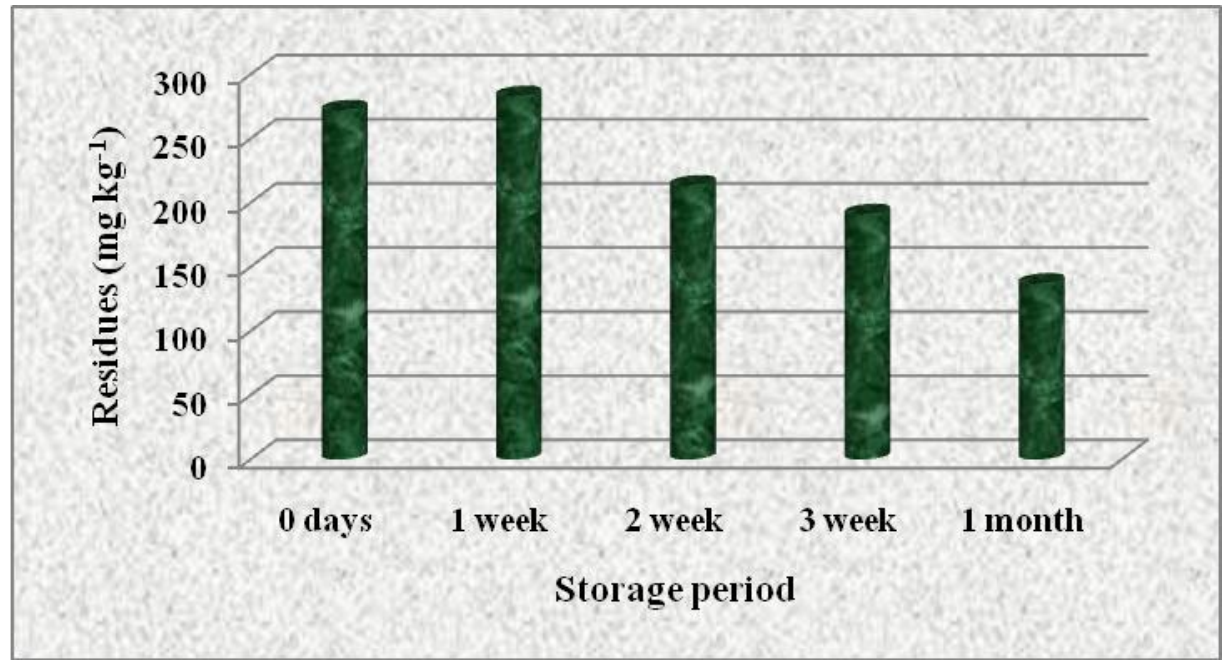

Fig.3 Dissipation of carboxin in seedlings of sunflower

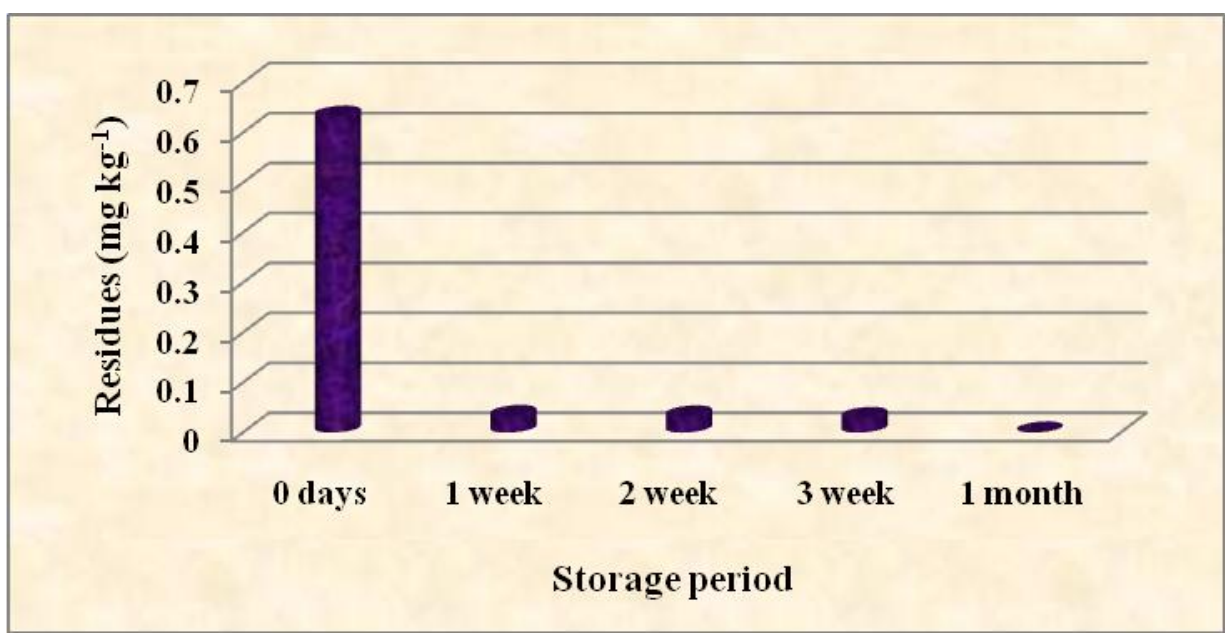

\section{Dissipation in seedlings}

Dissipation pattern of carboxin in seedlings was studied and the data is presented in Table 3. There was a gradual decrease observed in carboxin residual values from seedling emergence to one month age of seedlings (Fig. 3). Significantly highest residues of carboxin were recorded in seedlings at immediately (zero days) after emergence $\left(0.632 \mathrm{mg} \mathrm{kg}^{-1}\right)$ followed by one week age $\left(0.033 \mathrm{mg} \mathrm{kg}^{-1}\right)$ which was at par with two weeks $\left(0.032 \mathrm{mg} \mathrm{kg}^{-1}\right)$ and three weeks age of seedlings $\left(0.029 \mathrm{mg} \mathrm{kg}^{-1}\right)$. Fungicide residues were not recovered from seedlings of one month age. The residues dissipated by 94.78 , 94.94, 95.41 and $100.00 \%$ in one week, two weeks, three weeks and one month age seedlings respectively.

Similar gradual decrease in fungicide residues after application on crop was reported earlier by Sahoo et al., (2012) in chilli and Malhat (2013) in tomato. The previous studies of various scientists were mainly focussed on the topics like pesticide residue dissipation and safe consumption intervals after pesticidal spray on vegetables, fruits and other food 
crops. In the present investigation an attempt was made to study the fungicide residues in seeds and seedlings grown from treated seeds. This helps in knowing the fate of fungicide entered into seed tissue and the fungicidal persistence in seedlings after germination of treated seeds that offers protection against seed and soil borne pathogens.

It was evident from the results of the present study that, fungicide residues in seed increased slightly upto one week storage period and then started decline upto one month period of storage. Whereas, the residues were found high in seedlings at zero days after emergence with its gradual decline in one month age of the seedlings. It was also confirmed that, the residues of carboxin were higher in seeds when compared to seedlings and this might be due to the complexity in seed matrix and occurrence of various physiological activities at the time of seedling emergence and its further growth. The highest residues of carboxin at one week after storage in sunflower seeds respectively could be attributed to the absorption and retention of toxicant by the inner seed tissue over a period of time.

\section{References}

Afzal, R., Mughal, S.M., Munir, M., Sultana, K., Qureshi, R., Arshad, M and Laghari, M.K. 2010.Mycoflora associated with seeds of different sunflower cultivars and its management. Pakistan Journal of Botany. 42(1): 435-445.

AOAC Official Methods. 2007.01. Pesticide residues in foods by acetonitrile extraction and partitioning with magnesium sulphate. Official Methods of Analysis of AOAC International. $18^{\text {th }}$ ed. 2011. 17-26.

Indiastat.

2013-14. http://www.indiastat.com/agriculture/2/ commercialcrops/17188/oilseeds/17204/ stats.aspx.

Malhat, F.M., 2013. Persistence of metalaxyl residues on tomato fruit using high performance liquid chromatography and QuEChERS methodology. Arabian Journal of Chemistry. 1-4.

Maude, R.B., 1996. Seedborne Diseases and Their Control, Principles and Practice. CAB International. Wallingford. 280.

Sahoo, S.K., Jyot, G., Battu, R.S and Singh, B. 2012. Dissipation kinetics of trifloxystrobin and tebuconazole on chili and soil. Environmental Contamination Toxicology. 88(3):368371.

SANCO. 12571/2013. http://www.crlpesticides.eu/docs/public/tmplt_article.a sp?CntID=727 \&LabID=100\&Lang=EN .html.

Tanaka, B., Maeda, J.A and Plazas, I. 2001. Fungal microflora con seeds storage environment. Scientia Agricola. 58: 501-508.

\section{How to cite this article:}

Srinivas, A., B. Pushpavathi, B.K.M. Lakshmi and Shashibushan, V. 2017. Determination of Persistence of Fungicide in Seeds and Seedlings of Sunflower. Int.J.Curr.Microbiol.App.Sci. 6(10): 1913-1919. doi: https://doi.org/10.20546/ijcmas.2017.610.230 